\title{
Peran Perpustakaan Lembaga Pemasyarakatan Klas I Malang dalam meningkatkan literasi informasi narapidana
}

\author{
Karina Okta Bella ${ }^{1}$, Mutia Indriyani ${ }^{2}$, Chamdi Fajar ${ }^{3}$ \\ ${ }^{12}$ Program Studi Ilmu Perpustakaan, Universitas Negeri Malang \\ Jl. Semarang No.5, Lowokwaru, Malang, Jawa Timur, Indonesia 65145 \\ E-mail: 1karinaabellaa@gmail.com, 2mindriyani98@gmail.com, 3fajarchamdi@gmail.com
}

Received: December 2018; Accepted: June 2019; Published: June 2019

\begin{abstract}
Information literacy is a social capital for today's millennials as information literacy can make a difference for a better life. Every individual has the right to obtain and use information, including inmates. However, inmates have limited access to information while in prison; not all useful information can be obtained easily. Based on this fact, research on the role of libraries in improving prisoners' information literacy at the Correctional Institution Class I in Malang is essential to determine the library's influence on prisoners' information literacy. The purpose of this study was to find out about the role of the library in improving prisoner's information literacy. This study used the descriptive qualitative method with a qualitative approach. The data collection techniques through interviews, observation, and study literature. Study results indicated that the Library of the Correctional Institution Class I in Malang had a role as the primary source of information, a place for creating, and a place that provides learning activities for inmates. Information literacy at the Correctional Institution Class I in Malang applies local wisdom which is not carried out by other specialized libraries, such as library staff that does not have library science education backgrounds, the library collection contains religious, folklore, general knowledge, and skill books. The library's role in improving information literacy of prisoners can be seen from the works produced by the inmates, such as paintings, plant cultivation, and books that tell about their daily lives in prison.
\end{abstract}

Keywords: Prison library; Special library; Information literacy; Local wisdom; Inmates

\begin{abstract}
Abstrak
Literasi informasi menjadi modal sosial bagi masyarakat millennial saat ini, karena dapat mengubah kehidupan seseorang menjadi lebih baik. Setiap individu berhak untuk mendapatkan serta memanfaatkan informasi, tidak terkecuali pada narapidana. Namun, narapidana memiliki akses informasi yang terbatas ketika berada di dalam penjara serta tidak semua informasi mudah diperoleh. Berdasarkan hal tersebut, penelitian tentang peran perpustakaan dalam meningkatkan literasi informasi narapidana di Lembaga Pemasyarakatan Klas I Malang penting dilakukan untuk mengetahui pengaruh perpustakaan terhadap literasi informasi narapidana. Tujuan penelitian ini adalah untuk mengetahui bagaimana peran perpustakaan dalam meningkatkan literasi informasi para narapidana. Metode yang digunakan dalam penelitian menggunakan metode penelitian deskriptif melalui pendekatan kualitatif. Teknik pengumpulan data dilakukan melalui wawancara, observasi dan studi literatur. Hasil penelitian menunjukkan bahwa Perpustakaan Lembaga Pemasyarakatan Klas I Malang memiliki peran sebagai sumber informasi utama, wadah untuk berkreasi, serta menyediakan tempat untuk kegiatan pembelajaran bagi para narapidana. Literasi informasi narapidana di Lembaga Pemasyarakatan Klas I Malang memiliki kearifan lokal yang tidak dimiliki oleh perpustakaan khusus lainnya, seperti pada petugas perpustakaan yang tidak memiliki latar belakang pendidikan ilmu perpustakaan, subjek koleksi yang dimiliki berupa subjek keagamaan, cerita rakyat, pengetahuan umum, serta buku keterampilan. Peran perpustakaan dalam meningkatkan literasi informasi para narapidana dapat dilihat dari karyakarya yang dihasilkan oleh para narapidana, yaitu berupa karya seni lukisan, budidaya tanaman, serta buku yang menceritakan tentang kehidupan sehari-hari narapidana di dalam lembaga pemasyarakatan.
\end{abstract}

Kata Kunci: Perpustakaan lembaga pemasyarakatan; Perpustakaan khusus; Literasi informasi; Kearifan lokal; Narapidana 


\section{PENDAHULUAN}

Lembaga

pemasyarakatan

merupakan lembaga binaan bagi warga binaan yang sedang terkena hukuman akibat beberapa tindak pidana. Aninda (2013) menjelaskan bahwa dalam UndangUndang Nomor 12 Tahun 1995 Pasal 1 Ayat (3) menyebutkan bahwa, "Lembaga pemasyarakatan adalah tempat untuk melaksanakan pembinaan narapidana dan anak didik pemasyarakatan. Selain itu, dalam Pasal 1 Ayat (5) juga disebutkan bahwa, "Pengertian warga binaan pemasyarakatan adalah narapidana, anak didik pemasyarakatan, dan klien pemasyarakatan" (Aninda, 2013).

Badan Pengembangan dan Pembinaan Bahasa (2018) menjelaskan arti narapidana adalah, "Orang hukuman (orang yang sedang menjalani hukuman karena tindak pidana)." Narapidana menjadi orang yang sedang diasingkan karena dampak negatif perbuatannya. Walaupun begitu, narapidana masih memiliki hak dalam, "Mendapatkan bahan bacaan dan mengikuti siaran media massa lainnya yang tidak dilarang" (Aninda, 2013).

Lembaga Pemasyarakatan (LAPAS) menjadi wadah bagi narapidana dalam menciptakan budaya lokal sendiri yang dilakukan secara turun-temurun. Budaya lokal tersebut salah satunya adalah pemanfaatan perpustakaan dan kegiatan literasi oleh narapidana. Lingkungan narapidana yang bersifat heterogen menjadi tantangan tersendiri bagi perpustakaan dalam memberikan layanan informasi, seperti bahan pustaka kepada narapidana. Informasi yang dapat digunakan narapidana sangat terbatas sehingga hanya informasi dengan konten tertentu yang dapat diakses narapidana.
Perpustakaan yang terdapat pada Lembaga Pemasyarakatan (LAPAS) merupakan perpustakaan khusus sehingga pengguna pelayanan pun bersifat khusus, yakni para narapidana saja. Maka, hal ini menyebabkan narapidana memiliki akses informasi terbatas. Perpustakaan khusus sendiri ialah,

"Perpustakaan yang dibentuk oleh suatu lembaga baik pemerintah maupun swasta, perusahaan atau asosiasi yang menangani bidang tertentu dengan tujuan untuk memenuhi kebutuhan informasi di lingkungan sebagai pengembangan dan peningkatan lembaga maupun kemampuan sumber daya manusia" (Aninda, 2013).

Adapun perpustakaan khusus menurut Surachman (2013), merupakan "Perpustakaan yang didirikan untuk mendukung visi dan misi lembagalembaga khusus dan berfungsi sebagai pusat informasi khusus terutama berhubungan dengan penelitian dan pengembangan." Perpustakaan khusus biasanya juga memiliki karakteristik khusus apabila dilihat dari fungsi, subyek yang ditangani, koleksi yang dikelola, pemakai yang dilayani, dan kedudukannya. Kedudukan atau status dapat berarti di bawah naungan suatu lembaga, badan atau organisasi; tenaga yang mengelola memiliki kemampuan spesifik yang terkait dengan bidang subjek perpustakaan; koleksi yang dimiliki dan dilayankan terbatas pada subyek yang menjadi minat tertentu dari pemustaka atau penggunanya; dan pengguna yang berasal dari komunitas atau kalangan tertentu yang mempunyai minat tertentu pula.

LAPAS Klas I Malang merupakan salah satu lembaga yang memiliki 
perpustakaan diperuntukkan bagi para narapidana. Perpustakaan tersebut memiliki koleksi berupa buku bacaan serta kegiatan untuk meningkatkan literasi informasi narapidana. Salah satu kegiatan literasi di Perpustakaan Lembaga Pemasyarakatan (LAPAS) Klas I Malang adalah penyelenggaraan kegiatan belajar mengajar bagi narapidana yang dilaksanakan untuk mempersiapkan narapidana yang ingin mengikuti ujian paket A, B, C serta paket Buta Huruf (BTH) untuk mendapatkan ijazah yang dapat digunakan para narapidana dalam mencari pekerjaan ketika masa tahanan sudah habis.

\section{Perpustakaan}

Lembaga

Pemasyarakatan (LAPAS) Klas I Malang merupakan perpustakaan khusus dalam ruang lingkup lokal yang mempunyai keunikan dalam membangun budaya literasi informasi. Perpustakaan ini memiliki nilai kebiasaan yang terbangun secara alamiah serta dilakukan secara turun-temurun dalam lingkup lapas dalam beradaptasi dengan lingkungan.

Tambunan (2013) menjelaskan bahwa ciri-ciri perpustakaan khusus yakni, "Koleksi informasi yang dimiliki lebih diutamakan untuk memenuhi kebutuhan organisasi induk, berada di bawah suatu organisasi induk, masyarakat yang dilayani terbatas pada staf yang ada di lingkungan organisasi induk dan anggota asosiasi yang berada di organisasi tersebut." Perpustakaan Lembaga Pemasyarakatan (LAPAS) Klas I Malang sesuai ciri di atas memiliki pengguna perpustakaan yakni warga binaan atau narapidana dan staf yang bekerja pun khusus atau berasal dari lembaga tersebut. Selain itu, perpustakaan menyediakan informasi berupa koleksi dengan subjek tertentu (koleksinya terbatas) yang diperuntukkan bagi narapidana.

Lembaga Pemasyarakatan (LAPAS) Klas I Malang masih menyediakan informasi yang masih terbatas. Meskipun begitu, para narapidana tetap memiliki kesempatan yang sama seperti masyarakat umum untuk meningkatkan literasinya. Hal ini sesuai dengan UU No. 43 Tahun 2007 dalam Persia and Rohmiyati (2013) yang menyebutkan bahwa, gerakan nasional gemar membaca yang dilaksanakan pemerintah melibatkan seluruh masyarakat, tidak terkecuali masyarakat yang menyandang status narapidana.

Bando (2018) dalam Subakti (2018) menyatakan bahwa

"Paradigma terhadap warga binaan harus berubah dan disesuaikan konteks saat ini. Warga binaan dapat berubah kehidupannya ke arah yang lebih baik dengan membaca buku yang menginspirasi dan memotivasi. Dengan demikian, membaca buku dapat dijadikan acuan untuk memperoleh remisi."

Sesuai rujukan ini, peningkatan literasi informasi dapat dilakukan narapidana. Narapidana merupakan masyarakat yang mempunyai hak untuk mendapatkan informasi. Namun, para narapidana Lembaga Pemasyarakatan (LAPAS) Klas I Malang masih memiliki keterbatasan akses dalam memperoleh informasi yang masih dibatasi oleh pihak Lembaga Pemasyarakatan (LAPAS). Hal ini bertujuan agar informasi yang diperoleh para narapidana tidak disalahgunakan untuk kepentingan yang dapat merugikan narapidana, pihak Lembaga Pemasyarakatan (LAPAS) dan masyarakat. 
Perpustakaan

Lembaga

Pemasyarakatan (LAPAS) Klas I Malang hanya memfasilitasi para narapidana melalui penyediaan informasi tentang agama dan keterampilan, serta memfasilitasi narapidana dalam melakukan kegiatan positif untuk meningkatkan kemampuan literasi, seperti menjalin kerja sama dengan Komunitas UMengajar. Narapidana hanya memanfaatkan fasilitas perpustakaan seadanya saja. Walaupun begitu, hal ini telah memunculkan kearifan lokal di lingkungan Lembaga Pemasyarakatan (LAPAS).

Jaeni (2017) berpendapat bahwa, "Pengetahuan lokal atau biasa disebut dengan kearifan lokal dapat diartikan sebagai pengetahuan yang dengan caranya sendiri masyarakat memandang dunia atau lingkungannya." Begitu pun dengan para narapidana di Lembaga Pemasyarakatan (LAPAS) Klas I Malang. Mereka belajar memandang sisi positif atas keadaan terkungkung di dalam jeruji.

Berdasarkan latar belakang masalah di atas, penelitian ini penting dilakukan dengan tujuan untuk mengetahui: 1) peran Perpustakaan Lembaga Pemasyarakatan (LAPAS) Klas I Malang dalam meningkatkan literasi informasi para narapidana, 2) informasi apa yang digunakan narapidana di Perpustakaan Lembaga Pemasyarakatan (LAPAS) Klas I Malang, 3) budaya lokal apa yang diciptakan narapidana dalam kegiatan literasi di Perpustakaan Lembaga Pemasyarakatan (LAPAS) Klas I Malang, dan 4) karya ataupun produk apa saja yang dihasilkan narapidana selama menjalani masa tahanan di Perpustakaan Lembaga Pemasyarakatan (LAPAS) Klas I Malang.

\section{METODE PENELITIAN}

Penelitian ini menggunakan metode penelitian deskriptif melalui pendekatan kualitatif. Penelitian menghasilkan data deskriptif atau paparan mengenai peran Perpustakaan Lembaga Pemasyarakatan (LAPAS) Klas I Malang dalam meningkatkan literasi informasi mengenai perspektif kearifan lokal narapidana. Sumber data menggunakan sumber data primer yakni sumber data yang langsung diperoleh dari sumber pertama dan dikumpulkan oleh peneliti yakni dari wawancara melalui informan dan observasi langsung ke Lembaga Pemasyarakatan (LAPAS) Klas I Malang. Populasi dalam penelitian ini adalah narapidana Lembaga Pemasyarakatan (LAPAS) Klas I Malang. Untuk sampel penelitian adalah narapidana dan petugas Lembaga Pemasyarakatan (LAPAS) Pengelola Pembinaan Kepribadian. Teknik penentuan populasi serta sampel menggunakan teknik purposive sampling (untuk menentukan perpustakaan dan informan yang diteliti berdasarkan kriteria tertentu).

Subjek dari penelitian ini adalah narapidana yang mengelola perpustakaan Lembaga Pemasyarakatan (LAPAS) dan petugas bagian pembinaan narapidana. Teknik pengumpulan data dalam penelitian ini terdiri dari wawancara dan observasi. Pengambilan kedua narasumber tersebut karena keduanya merupakan pihak yang mengetahui kondisi di dalam Perpustakaan Lembaga Pemasyarakatan (LAPAS) Klas I Malang.

Teknis analisis data yang dilakukan sesuai Moleong (2010) dalam Afifah (2014) yakni, "Bersifat induktif kualitatif". Peneliti menganalisis data sesuai data yang diperoleh, dari 
wawancara dan observasi kemudian diolah, dan dianalisis. Akhirnya, peneliti menarik kesimpulan sebagai tahap akhir dari penelitian.

\section{HASIL DAN PEMBAHASAN}

Menurut Undang-Undang Nomor 43 Tahun 2007 Pasal 1 Ayat (7) dalam Persia and Rohmiyati (2013) menjelaskan bahwa perpustakaan khusus adalah, "Perpustakaan yang diperuntukkan secara terbatas bagi pemustaka di lingkungan lembaga pemerintah, lembaga masyarakat, lembaga pendidikan keagamaan, rumah ibadah, atau organisasi lain." Pendapat lain, menurut Aninda (2013), perpustakaan khusus ialah, “Perpustakaan yang dibentuk oleh suatu lembaga baik pemerintah maupun swasta, perusahaan atau asosiasi yang menangani bidang tertentu dengan tujuan untuk memenuhi kebutuhan informasi di lingkungannya sebagai pengembangan dan peningkatan lembaga maupun kemampuan sumber daya manusia."

Perpustakaan khusus memiliki ciri di antaranya koleksi perpustakaan lebih diutamakan untuk memenuhi kebutuhan organisasi induk, perpustakaan berada di bawah suatu organisasi induk, pengguna perpustakaan yang dilayani terbatas di lingkungan organisasi induk dan anggota asosiasi yang berada di organisasi tersebut (Tambunan, 2013). Perpustakaan Lembaga Pemasyarakatan (LAPAS) Klas I Malang berada di bawah organisasi Lembaga Pemasyarakatan, subjek koleksi perpustakaan mencakup koleksi yang bermanfaat untuk menambah wawasan dan menghibur bagi para narapidana.

$$
\text { Perpustakaan Lembaga }
$$

Pemasyarakatan (LAPAS) Klas I Malang telah memfasilitasi kegiatan membaca, dan memiliki kegiatan dalam memberikan pengetahuan serta meningkatkan kemampuan narapidana dalam mencari, memanfaatkan, serta menentukan kebutuhan informasi ke arah yang lebih positif. Berdasarkan kegiatan tersebut, para narapidana dapat meningkatkan keterampilan serta memperoleh hak yang sama meskipun masih berada dalam tahanan.

Perpustakaan tersebut juga merupakan salah satu sarana untuk mewujudkan keinginan dan harapan warga binaan dalam meraih cita-cita. Warga binaan, yakni narapidana tetap dapat belajar dan mengasah keterampilan sebagai bekal ketika terbebas dari Lembaga Pemasyarakatan (LAPAS) dan terjun ke masyarakat melalui perpustakaan. Ketika warga binaan berada di masyarakat, mereka akan menjadi sosok yang lebih baik dan bermanfaat.

Selain itu, Perpustakaan Lembaga Pemasyarakatan (LAPAS) Klas I Malang dapat digunakan sebagai wadah bagi narapidana yang putus sekolah karena terjerat kasus pidana. Mereka mencari informasi mengenai bahan belajar yang dibutuhkan untuk mengikuti kegiatan sekolah di dalam Lembaga Pemasyarakatan (LAPAS).

Perpustakaan Lembaga Pemasyarakatan (LAPAS) Klas I Malang tidak memiliki pustakawan yang memiliki latar belakang pendidikan ilmu perpustakaan sehingga perpustakaan dikelola Bagian Pengelolaan Pembinaan dan Kepribadian Lembaga Pemasyarakatan Klas I Malang. Namun, jumlah petugas Lembaga Pemasyarakatan (LAPAS) sangat terbatas sehingga mereka merekrut narapidana untuk dapat 
membantu mengelola perpustakaan Lembaga Pemasyarakatan (LAPAS). Maka, narapidana yang bersedia membantu perpustakaan pun menjadi pengelola perpustakaan.

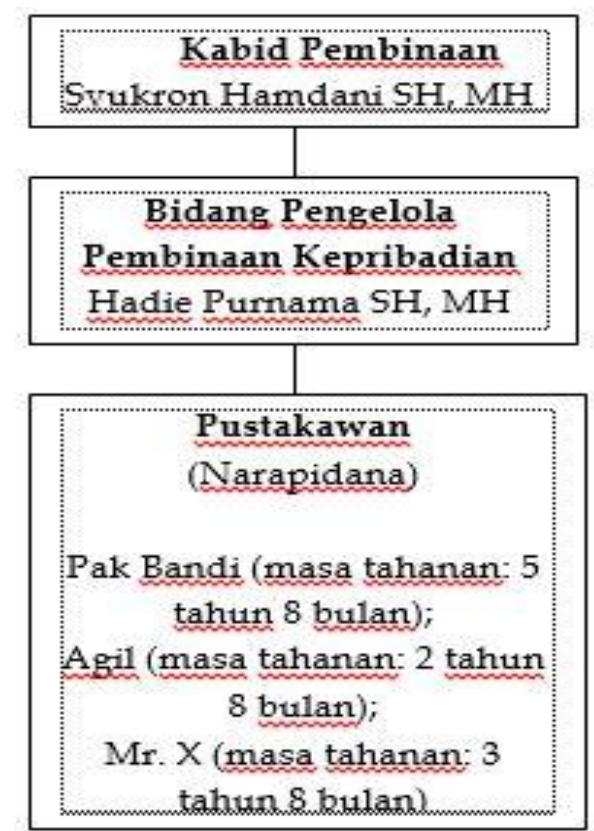

Gambar 1. Struktur organisasi Perpustakaan Lembaga Pemasyarakatan Klas I Malang

Sumber: Hasil Penelitian, 2018

Hal unik yang tidak terdapat di perpustakaan khusus lainnya adalah di perpustakaan tersebut, pengelola perpustakaan mendapatkan julukan 'pustakawan' setelah direkrut oleh pihak Lembaga Pemasyarakatan (LAPAS). Perekrutan narapidana menjadi pustakawan berpengaruh terhadap strata sosial narapidana tersebut di lingkungan Lembaga Pemasyarakatan (LAPAS). Narapidana yang bertugas sebagai pustakawan akan lebih terhormat daripada narapidana yang tidak direkrut karena mereka akan mendapatkan perlakuan khusus, seperti ketika narapidana lain masuk sel, pustakawan bisa sedikit lebih bebas untuk melakukan aktivitas bekerja di perpustakaan dan di luar sel tahanan.
Sesuai temuan data di atas, di Perpustakaan Lembaga Pemasyarakatan (LAPAS) Klas I Malang memiliki kearifan lokal yang tidak terdapat di perpustakaan di luar lapas. Pustakawan di perpustakaan luar lapas pada umumnya dianggap sebagai profesi 'buangan' yang jarang diminati masyarakat sedangkan untuk pustakawan pada perpustakaan Lembaga Pemasyarakatan (LAPAS) merupakan profesi istimewa. Di mana narapidana yang mampu menjadi pustakawan merupakan kehormatan tersendiri atau menjadi narapidana terhormat di antara narapidana yang lain. Selain mereka dihormati dalam lingkungan lapas, narapidana juga mendapatkan remisi karena dianggap sudah melakukan hal positif serta mengabdi kepada lembaga tersebut.

Narapidana yang direkrut menjadi pustakawan di Perpustakaan Lembaga Pemasyarakatan (LAPAS) harus memenuhi kriteria yang ditentukan pihak Lembaga Pemasyarakatan (LAPAS) yang bekerja sama dengan Perpustakaan Umum Kota Malang. Adapun kriteria narapidana untuk menjadi pustakawan di Lembaga Pemasyarakatan (LAPAS), di antaranya, pertama, narapidana minimal telah menempuh jenjang pendidikan Sekolah Menengah Atas karena dianggap telah dewasa dalam pola berpikir. Kedua, narapidana memiliki dedikasi, berkorban waktu dan pikiran untuk dapat bekerja di perpustakaan. Ketiga, narapidana memiliki loyalitas, rasa tanggung jawab dan kesetiaan. Keempat, narapidana dapat mengevaluasi sikap karena pihak Lembaga Pemasyarakatan (LAPAS) akan mengevaluasi perilaku narapidana melalui riwayat hidupnya selama berada di Lembaga Pemasyarakatan (LAPAS). 


\begin{abstract}
Setelah pihak Lembaga Pemasyarakatan (LAPAS) merekrut pustakawan, lalu diadakan pembinaan dan pelatihan kepustakawanan kepada narapidana calon pustakawan. Materi pembinaan dan pelatihan yang diberikan ialah bagaimana menyeleksi dan mengelola koleksi. Seorang narapidana yang menjadi pustakawan, akan mendapatkan pengetahuan dan pengalaman yang baru. Selain itu, narapidana akan memperoleh remisi sebesar 1/3 dari remisi sebelumnya.
\end{abstract}

Pemustaka berdasarkan UU No. 43 Tahun 2007 Pasal 1 ayat (9) adalah, "Perseorangan, kelompok orang, masyarakat, atau lembaga yang memanfaatkan fasilitas layanan perpustakaan." (Persia \& Rohmiyati, 2013). Perpustakaan Lembaga Pemasyarakatan (LAPAS) Klas I Malang memiliki pemustaka yakni narapidana yang bersifat heterogen yang berasal dari latar belakang sosial yang bebeda-beda, mulai dari narapidana yang berusia di bawah umur hingga narapidana yang berusia paruh baya. Sesuai latar belakang pendidikan, terdapat narapidana yang tidak pernah mencicipi bangku sekolah hingga narapidana yang bergelar profesor. Berdasarkan jenis dan tingkat kejahatan pun beraneka ragam, mulai dari kejahatan berupa pembunuhan, narkoba, hingga kasus korupsi. Keberagaman subjek yang ada di lingkungan Perpustakaan Lembaga Pemasyarakatan (LAPAS) Klas I Malang sendiri juga merupakan kearifan lokal yang tidak dimiliki perpustakaan khusus lainnya.

Pada umumnya, dalam manajemen perpustakaan khusus memerlukan spesialisasi subjek (subject specialist) yang berfungsi membantu mengolah bahan pustaka serta membantu pemustaka.
Selain itu, spesialisasi subjek (subject specialist) diperlukan perpustakaan agar pustakawan dapat memahami bidang tertentu, serta memiliki keahlian dalam mengolah bahan pustaka dan melakukan penelusuran informasi, baik secara manual maupun menggunakan teknologi informasi.

Maka, untuk suatu perpustakaan khusus diperlukan staf profesional yang memiliki latar belakang pendidikan pada bidang tertentu yang berhubungan dengan kegiatan organisasi induk dan memiliki pendidikan tambahan di bidang perpustakaan. Perbandingan kebutuhan antara staf profesional dan nonprofesional ditentukan oleh misi, layanan yang diberikan dan frekuensi kedatangan pemakai ke perpustakaan, (Tambunan, 2013). Akan tetapi, menajemen perpustakaan khusus di Lembaga Pemasyarakatan (LAPAS) berbeda dengan perpustakaan lainnya, yakni ada nilai kearifan lokal atau keunikan tersendiri yang tidak dimiliki perpustakaan khusus lain.

Keunikan tersebut menjadi kearifan lokal yang terbentuk di lingkungan Perpustakaan Lembaga Pemasyarakatan (LAPAS), misalnya pustakawan yang mengelola perpustakaan tidak memahami bidang pengelolaan perpustakaan sehingga tidak ada subject specialist dalam koleksi tersebut. Selain itu, koleksi perpustakaan yaitu koleksi umum dan koleksi yang dapat menjadikan narapidana menjadi pribadi yang lebih baik, seperti koleksi keagamaan, keterampilan dan sebagainya.

Pustakawan yang mengelola Perpustakaan Lembaga Pemasyarakatan (LAPAS) ialah yang memiliki latar belakang narapidana atau orang yang pernah melanggar hukum atau tindak 
kejahatan. Narapidana tersebut memiliki kategori telah terpercaya oleh pihak Lembaga Pemasyarakatan (LAPAS) karena memiliki perilaku positif lebih banyak selama dalam masa tahanan. Selain itu, narapidana tersebut juga merupakan narapidana yang ditakuti narapidana lain sehingga pustakawan dapat mengontrol warga binaan yang lain agar tetap tertib dalam pemanfaatan perpustakaan.

Oleh karena itu, manajemen perpustakaan yang ada di Lembaga Pemasyarakatan (LAPAS) tentunya berbeda dengan perpustakaan khusus lainnya. Pertama, perbedaan dalam lembaga yang menaunginya. Kedua, perbedaan teknologi informasi, disebabkan peraturan yang melarang para narapidana terhubung dengan dunia luar melalui teknologi informasi. Peraturan Lembaga Pemasyarakatan (LAPAS) ini dibuat untuk mencegah adanya transaksi ilegal yang mungkin bisa dilakukan narapidana.

Ketiga, perbedaan minimnya perhatian pihak Lembaga Pemasyarakatan (LAPAS) terhadap perpustakaan sehingga mengakibatkan perpustakaan melakukan kegiatan manajemen secara manual. Perpustakaan Lembaga Pemasyarakatan (LAPAS) Klas I Malang melakukan manajemen perpustakaan yang dilakukan yakni pertama kerja sama. Perpustakaan Lembaga Pemasyarakatan (LAPAS) Klas I Malang didirikan untuk menambah wawasan, pengetahuan serta pengalaman para narapidana. Perpustakaan tersebut dikelola pustakawan dan tamping Lembaga Pemasyarakatan (LAPAS) (anggota narapidana yang dipercaya membantu pustakawan). Jadi, tamping Lembaga Pemasyarakatan (LAPAS) dipercaya untuk mengelola perpustakaan dan nantinya akan mendapatkan pelatihan dalam pengelolaan perpustakaan. Tamping Lembaga Pemasyarakatan (LAPAS) mendapat pelatihan agar dapat mengelola koleksi di perpustakaan dengan baik seperti perpustakaan pada umumnya. Hal tersebut dilakukan mengingat pustakawan Lembaga Pemasyarakatan (LAPAS) berasal dari pihak narapidana, di mana narapidana tidak memiliki latar belakang keilmuan ilmu perpustakaan. Oleh karena itu, mereka perlu mengikuti pembekalan mengenai perpustakaan sebelum terjun mengelola perpustakaan.

Pihak Lembaga Pemasyarakatan (LAPAS) menjalin kerja sama dengan Perpustakaan Umum Kota Malang dalam pelaksanaan kegiatan pembekalan kepada tamping Perpustakaan, berupa pelatihan pengolahan koleksi perpustakaan, dalam mengklasifikasikan dan melabelkan buku. Selain itu, Perpustakaan Lembaga Pemasyarakatan (LAPAS) Klas I Malang bekerja sama dengan Perpustakaan Nasional Republik Indonesia dan Perpustakaan Umum Kota Malang dalam kegiatan dropping buku yang dilakukan setiap tiga bulan sekali. Kegiatan ini berupa kunjungan Perpustakaan Umum Kota Malang ke Lembaga Pemasyarakatan (LAPAS) Klas I Malang menggunakan mobil perpustakaan (perpustakaan keliling) sebagai bentuk kegiatan dropping buku.

\begin{tabular}{lrr}
\multicolumn{1}{c}{ Hal ini dilakukan } & untuk \\
memudahkan & para narapidana & dalam \\
memperoleh & informasi dan & ilmu \\
pengetahuan sehingga para narapidana & dalam \\
mengalami peningkatan & ditu, \\
kemampuan literasi informasi. Selain itu, & perpustakaan keliling dari Perpustakaan \\
Umum Kota Malang membantu para \\
narapidana dalam menerapkan ilmu yang
\end{tabular}


diperoleh di lingkungan masyarakat ketika mereka telah keluar dari Lembaga Pemasyarakatan (LAPAS) (masa tahanan telah habis).

Kedua, Perpustakaan Lembaga Pemasyarakatan (LAPAS) Klas I Malang dalam melakukan manajemen perpustakaan berupa pengadaan. Koleksi buku di Perpustakaan Lembaga Pemasyarakatan (LAPAS) Klas I Malang diperoleh dari pembelian secara mandiri serta sumbangan dari Perpustakaan Nasional Republik Indonesia. Jumlah koleksi yang dimiliki \pm 3.720 eksemplar yang terdiri dari buku bertema agama, cerita rakyat, fiksi, ilmu pengetahuan, serta buku keterampilan.

Ketiga, Perpustakaan Lembaga Pemasyarakatan (LAPAS) Klas I Malang dalam melakukan manajemen perpustakaan berupa pengolahan koleksi yang berasal dari sumber pembelian. Pustakawan Perpustakaan Lembaga Pemasyarakatan (LAPAS) Klas I Malang tidak melakukan kegiatan pengolahan terhadap koleksi buku yang berasal dari Perpustakaan Nasional Republik Indonesia dan Perpustakaan Umum Kota Malang, karena buku yang disumbangkan merupakan buku yang sudah dilabeli.

Koleksi buku yang didapatkan melalui pembelian secara mandiri dikelola sendiri oleh pihak Lembaga Pemasyarakatan (LAPAS) karena yang mengolah koleksi adalah pustakawan. Jadi pengolahan koleksi sedikit berbeda dari koleksi yang berasal dari Perpustakaan Nasional Republik Indonesia dan Perpustakaan Umum Kota Malang. Pengolahan koleksinya seperti pelabelan buku yang tidak menggunakan sistem klasifikassi Dewey Decimal Classification (DDC) tetapi menggunakan sistem klasifikasi sederhana yang mudah dipahami oleh petugas tamping Lembaga Pemasyarakatan (LAPAS) dan para narapidana.

$$
\text { Saputro and Amir }
$$

menyatakan bahwa perpustakaan khusus memiliki karakteristik yang dapat dilihat dari aspek, fungsi, subyek yang ditangani, koleksi yang dikelola, pengguna yang dilayani, dan kedudukannya. Sesuai karakteristik tersebut, Perpustakaan Lembaga Pemasyarakatan (LAPAS) Klas I Malang berfungsi sebagai penyedia informasi dan hiburan bagi para narapidana.

\section{Perpustakaan}

Pemasyarakatan (LAPAS)

Lembaga ketersediaan koleksi mengenai pengetahuan dan keterampilan umum, di mana subjek atau tema koleksi dibatasi pada subjek tertentu saja. Selain itu, koleksi perpustakaan berfungsi sebagai sarana rekreasi berupa penyediaan koleksi bahan bacaan seperti cerita rakyat dan novel. Koleksi tersebut merupakan koleksi yang sering dipinjam narapidana. Koleksi berjenis fiksi mampu menghibur narapidana ketika merasa bosan menjalani masa hukuman tahanan. Adapun karakteristik terakhir yaitu Perpustakaan Lembaga Pemasyarakatan (LAPAS) Klas I Malang memiliki kedudukan di bawah Lembaga Pemasyarakatan (LAPAS).

\section{Perpustakaan}

Lembaga

Pemasyarakatan (LAPAS) Klas I Malang dari segi pendidikan membantu dalam penyediaan ruang kelas yang digunakan untuk kegiatan program kejar paket bagi narapidana yang putus sekolah. Hal ini dilakukan agar narapidana tersebut dapat melanjutkan pendidikan atau mencari pekerjaan setelah habis masa hukuman tahanan.

$$
\text { Perpustakaan }
$$

Lembaga Pemasyarakatan (LAPAS) Klas I Malang 
pun memiliki fungsi kultural, misalnya perpustakaan memfasilitasi narapidana yang menyalurkan pengalaman selama menjadi tahanan melalui tulisan dalam berbentuk buku. Kegiatan ini bermanfaat bagi narapidana agar dapat berbagi (sharing) informasi kepada orang lain tentang suka duka selama menjalani masa tahanan, budaya lokal yang ada, serta kebiasaan di dalam Lembaga Pemasyarakatan (LAPAS) Klas I Malang.

Buku tersebut ditulis sendiri oleh narapidana, yang dibantu petugas Lembaga Pemasyarakatan (LAPAS) dalam kegiatan penyusunan buku. Buku yang ditulis narapidana ini tidak dapat disusun sendiri karena tidak tersedianya teknologi komputer di ruang tahanan. Namun, hal tersebut membawa dampak positif untuk Perpustakaan Lembaga Pemasyarakatan (LAPAS) Klas I Malang.

Narapidana memiliki keterbatasan dalam mengakses informasi. Hal ini menjadi dampak positif bagi Perpustakaan Lembaga Pemasyarakatan (LAPAS) Klas I Malang karena menjadi sumber informasi utama bagi narapidana. Narapidana dapat menggunakan informasi yang disediakan perpustakaan sebagai alat bantu dalam pemberdayaaan dan pengembangan kemampuan diri. Ini bertujuan agar para narapidana dapat menggunakan informasi dan ilmu yang telah dipelajari untuk mempraktikkan di masyarakat sehingga kedudukan fungsi sosialnya kembali di mata masyarakat setelah masa tahanannya habis.

Sesuai karakteristik yang telah dijabarkan di atas, peran Perpustakaan Lembaga Pemasyarakatan (LAPAS) Klas I Malang adalah sebagai sumber informasi utama bagi narapidana, sebagai tempat berkreasi dan menghabiskan waktu luang, serta sebagai tempat kegiatan pembelajaran para narapidana. Adapun kegiatan di Perpustakaan Lembaga Pemasyarakatan (LAPAS) Klas I Malang di antaranya sebagai pengembangan kepribadian, pengembangan kemampuan intelektual, dan peningkatan kemandirian.

$$
\text { Kegiatan }
$$

pengembangan

kepribadian berisi pemberian ilmu untuk memperdalam dan meningkatkan kesadaran beragama melalui penyediaan koleksi buku agama, serta program kejar paket bagi narapidana yang putus sekolah. Hal ini dilakukan agar narapidana tersebut bisa melanjutkan pendidikan atau mencari pekerjaan setelah habis masa tahanan.

Kegiatan dalam meningkatkan kemampuan intelektual narapidana berupa kegiatan yang disediakan perpustakaan melalui membaca buku. Perpustakaan Lembaga Pemasyarakatan (LAPAS) dalam menjalankan kegiatan membaca buku, telah menjalin kerja sama dengan Komunitas UMengajar yang dilaksanakan setiap satu bulan sekali. Selain itu, kegiatan dalam peningkatan kemandirian narapidana ialah melalui penyediaan buku keterampilan dalam berkarya dan buku mengenai kewirausahaan, seperti industri maupun pertanian.

Selain kegiatan di atas, perpustakaan pun berperan dalam kegiatan pelatihan keterampilan narapidana, seperti penyediaan bahan bacaan untuk membuat kerajinan hingga membuat karya tulis. Hasil karya berupa kerajinan bisa menambah nilai produktivitas narapidana. Di mana karya yang telah dihasilkan akan dijual kepada pengunjung Lembaga Pemasyarakatan (LAPAS) maupun masyarakat melalui kerjasama yang dijalin dengan penjual kerajinan di Kota Malang. Jadi, ketika 
terdapat pengunjung dari luar seperti sanak keluarga, mereka dapat membeli kerajinan yang dibuat oleh para narapidana. Karya lain yang dihasilkan para narapidana di Lembaga Pemasyarakatan (LAPAS) Klas I Malang yaitu karya tulis berupa buku yang menceritakan tentang pengalaman serta suka duka narapidana selama menjalani masa tahanan.

Menurut Ranganathan and Durga (2016), "The Association of College and Research Libraries defines information literacy as the set of skills needed to find, retrieve, analyses and use information." Sesuai rujukan ini, dapat dikatakan bahwa literasi informasi adalah satu rangkaian kemampuan individu untuk mengenali informasi saat diperlukan serta memiliki kemampuan untuk menemukan, mengevaluasi, dan menggunakan informasi tersebut secara efektif. Literasi informasi merupakan salah satu komponen penting yang harus dimiliki oleh setiap orang untuk berkontribusi dalam mencapai pembelajaran seumur hidupnya.

Istilah literasi informasi pertama kali diperkenalkan oleh Paul G. Zurkowski yang merupakan Pimpinan dari American Information Industry Association pada tahun 1974. Septiyantono (2014) dalam Junandi (2018) menyatakan bahwa, literasi informasi merupakan, "Kemampuan untuk memanfaatkan berbagai alat serta sumber-sumber informasi primer untuk memecahkan masalah mereka." Adapun pendapat Verzosa (2009) dalam Pattah (2014), "Literasi informasi adalah sebuah keahlian dalam mengakses dan mengevaluasi informasi secara efektif untuk memecahkan masalah dan membuat keputusan."
Jadi, dapat dikatakan bahwa literasi informasi merupakan kemampuan untuk menemukan, mengevaluasi, dan menggunakan informasi secara efektif yang dapat digunakan untuk memecahkan masalah dan mengambil keputusan serta mendukung pembelajaran sepanjang hayat seseorang. Literasi informasi memiliki fungsi penting bagi setiap individu. Seseorang dapat meningkatkan kualitas diri dalam rangka belajar seumur hidup melalui kemampuan literasi informasi. Ketika seorang individu memiliki keinginan untuk meningkatkan taraf hidup, maka individu tersebut memerlukan sesuatu yang lebih yakni melalui pengembangan diri dalam keterampilan, pendidikan atau kinerja yang lebih baik (Silvana, Fitriawati \& Saepudin, 2017).

Para narapidana dalam memahami literasi informasi maka memunculkan pengetahuan lokal atau kearifan lokal. Lalu, Kimbal, and Pangemanan (2017) mengatakan bahwa kearifan lokal ialah, “Gagasan atau nilai, pandangan setempat atau lokal yang bersifat bijaksana, penuh kearifan, bernilai baik yang tertanam dan diikuti oleh anggota masyarakatnya."

Wales (1949) dalam Sriyanto, Kurniawan, and Aji (2019) mengatakan bahwa kearifan lokal, "Which meant the ability of local culture to deal with foreign cultural influences when the two cultures were related." Kearifan lokal ialah kemampuan masyarakat dalam menyesuaikan diri terhadap budaya di daerahnya dan mampu menghadapi pengaruh budaya dari luar lingkungan. Berdasarkan pengertian tersebut terdapat tiga pokok pikiran utama, yakni karakter budaya, kelompok pemilik budaya, dan pengalaman hidup yang lahir dari karakter budaya. 
Di Lapas Klas I Malang, para narapidana tidak hanya memanfaatkan waktu luang untuk istirahat saja, tetapi mereka juga memanfaatkan waktu luang yang dimiliki untuk menambah wawasan dan keterampilan literasi informasi dengan membaca buku di perpustakaan. Pada bab sebelumnya, Perpustakaan Lapas Lembaga Pemasyarakatan (LAPAS) I Malang merupakan perpustakaan khusus untuk narapidana yang melayankan koleksi berupa buku dengan subjek agama, keterampilan dan fiksi.

Surachman (2013) memberikan pendapat bahwa perpustakaan khusus merupakan perpustakaan yang berada di bawah badan, institusi, lembaga atau organisasi bisnis, industri, ilmiah, pemerintah, dan pendidikan, misalnya perguruan tinggi, perusahaan, departemen, asosiasi profesi, instansi pemerintah dan lain sebagainya. Adapun ciri-ciri perpustakaan khusus, yakni, "Koleksi informasi yang ada lebih diutamakan untuk memenuhi kebutuhan organisasi induk, berada di bawah suatu organisasi induk, masyarakat yang dilayani terbatas pada staf yang ada di lingkungan organisasi induk dan anggota asosiasi yang berada di organisasi tersebut" (Tambunan, 2013).

Perpustakaan khusus terkadang memiliki ukuran ruangan dan koleksi yang kecil, dikelola pustakawan ahli, dan diperlukan spesialisasi subjek (subject specialist) dalam mengolah bahan pustaka. Hal ini dilakukan karena informasi yang disediakan bersifat khusus serta koleksi disesuaikan dengan kepentingan lembaga induk. Oleh sebab itu, staf profesional suatu perpustakaan khusus yang bertugas sebaiknya mempunyai latar belakang pendidikan bidang tertentu yang sesuai dengan kegiatan organisasi induk.
Meskipun demikian, Perpustakaan Lapas Lembaga Pemasyarakatan (LAPAS) Klas I Malang memiliki kearifan lokal yang tidak dimiliki perpustakaan khusus lainnya. Apabila dilihat dari jenis lembaganya, perpustakaan Lapas Lembaga Pemasyarakatan (LAPAS) seharusnya memuat koleksi seputar hukum. Namun, koleksi yang dimiliki adalah seputar keagamaan, cerita rakyat atau fiksi dan buku keterampilan. Hal tersebut sesuai dengan tujuan dari pendirian sistem pemasyarakatan dari Selvina (2017) yakni agar, "Warga binaan menjadi warga negara yang baik, menyadari kesalahan, memperbaiki diri, dan tidak mengulangi tindak pidana, dan bertanggungjawab serta untuk bekal ketika bebas agar diterima oleh lingkungan masyarakat". Maka untuk mewujudkan tujuan tersebut diperlukan fasilitas penunjang dalam Lembaga Pemasyarakatan (LAPAS). Salah satunya seperti menyediakan perpustakaan yang melayankan koleksi bersubjek agama dan keterampilan kepada para narapidana.

$$
\text { Perpustakaan dalam Lembaga }
$$

Pemasyarakatan (LAPAS) telah meningkatkan kemampuan literasi para narapidana. Hal ini terbukti dengan adanya buku yang diterbitkan Lembaga Pemasyarakatan (LAPAS) Klas I Malang yang penulisnya adalah para penghuni lapas. Lembaga Pemasyarakatan (LAPAS) Klas I Malang meluncurkan buku tentang kisah warga binaan dalam memperingati Hari Bhakti Pemasyarakatan ke-52. Bukubuku yang dirilis tersebut berjudul "52 Kisah Warga Binaan Pemasyarakatan (WBP) Lapas Malang Menuju Langkah Pasti" yang menceritakan 52 kisah penghuni Lembaga Pemasyarakatan (LAPAS) Klas I Lowokwaru, Kota Malang (Rahmawan, 2016). 
Selanjutnya, Krismono (2016) dalam Rahmawan (2016) memaparkan bahwa, "Buku tersebut dicetak sebanyak 200 buah yang separuhnya diberikan ke Lembaga Pemasyarakatan (LAPAS) Cipinang dan diharapkan dapat menginspirasi masyarakat luar maupun narapidana serta memberikan wawasan agar masyarakat tidak sampai masuk ke dalam Lembaga Pemasyarakatan (LAPAS)." Berdasarkan penerbitan buku tersebut, menunjukkan bahwa penyediaan perpustakaan di dalam Lembaga Pemasyarakatan (LAPAS) dapat memupuk literasi informasi dalam perspektif kearifan lokal para narapidana. Para narapidana melalui literasi informasi memperoleh manfaat untuk berbagi (sharing) informasi seputar kehidupan yang dijalaninya di dalam penjara kepada para pembaca buku.

Perpustakaan

Lembaga

Pemasyarakatan (LAPAS) Klas I Malang memiliki kearifan lokal lain yakni pengelolaan perpustakaan lapas dikelola oleh petugas Lembaga Pemasyarakatan (LAPAS) yang dibantu oleh tamping Lembaga Pemasyarakatan (LAPAS) atau narapidana yang dipercaya dan dipekerjakan di lembaga pemasyarakatan. Mereka dipilih karena memiliki perilaku dan sikap yang baik selama di Lembaga Pemasyarakatan (LAPAS). Hal ini berbeda dengan petugas perpustakaan atau pustakawan yang berada di perpustakaan khusus lembaga lain yang memiliki latar belakang pendidikan bidang ilmu perpustakaan dan informasi.

\section{Pustakawan}

Lembaga

Pemasyarakatan (LAPAS) atau tamping memiliki tugas untuk menjaga perpustakaan atau melayani pengguna yang ingin membaca koleksi perpustakaan. Selain itu, mereka juga turut membantu petugas Lembaga Pemasyarakatan (LAPAS) dalam menyiapkan keperluan yang dibutuhkan narapidana ketika akan mengikuti ujuan paket A, B maupun C di perpustakaan, seperti menata meja dan kursi ujian serta membersihkan ruangan ujian.

\section{SIMPULAN}

Berdasarkan penjelasan yang telah dipaparkan, dapat disimpulkan bahwa Perpustakaan Lembaga Pemasyarakatan (LAPAS) merupakan perpustakaan khusus yang melayani pemustaka narapidana, yang pengelolaan perpustakaannya dikelola oleh Kepala Sub Bidang Pengelola Pembinaan Kepribadian dengan dibantu narapidana sebagai pustakawan melalui kriteria tertentu. Manajemen perpustakaan dilakukan dengan menerapkan beberapa kaidah perpustakaan secara umum. Adapun peran Perpustakaan Lembaga Pemasyarakatan (LAPAS) Klas I Malang dalam meningkatkan literasi informasi narapidana merupakan suatu kearifan lokal tersendiri yang ada di Lembaga Pemasyarakatan (LAPAS) Klas I Malang. Perpustakaan Lembaga Pemasyarakatan (LAPAS) menjadi wadah bagi para narapidana untuk mengembangkan literasi informasinya. Narapidana sudah dapat dikatakan mampu meningkatkan kemampuan literasi informasi walaupun sumber informasi di perpustakaan masih terbatas. Indikator yang dapat dilihat dari kegiatan literasi informasi di Lembaga Pemasyarakatan (LAPAS) ini adalah adanya hasil karya dari narapidana, yaitu berupa buku, karya seni lukisan, dan budidaya tanaman. Keberadaan perpustakaan menjadi sangat penting bagi narapidana, selain sebagai sumber informasi utama, perpustakaan juga 
menjadi salah satu pilihan bagi narapidana untuk menghilangkan rasa bosan selama menjalani masa tahanan. Adapun koleksi yang disediakan yaitu berupa pengetahuan agama untuk menambah pengetahuan narapidana dalam beragama, koleksi pengetahuan umum yang dapat memperkaya wawasan narapidana, serta koleksi yang bersifat menghibur narapidana seperti novel. Kegiatan manajemen perpustakaan masih dilakukan secara manual karena minimnya perhatian dari pihak Lembaga Pemasyarakatan (LAPAS) terhadap perpustakaan. Diharapkan penelitian ini dapat dijadikan acuan untuk penelitian selanjutnya tentang bagaimana memanajemen perpustakaan khusus yang baik agar kemampuan literasi informasi para narapidana meningkat.

\section{DAFTAR PUSTAKA}

Afifah, D. (2014). Upaya masyarakat dalam menumbuhkan kesadaran akan pentingnya pendidikan formal: Studi kasus di Desa Sendang, Kragan, Rembang, Jawa Tengah (Skripsi). Universitas Islam Negeri Sunan Kalijaga, Yogyakarta. Retrieved from http:/ / digilib.uinsuka.ac.id/13546/1/BAB I, IV, DAFTAR PUSTAKA.pdf

Aninda, P. S. (2013). Pemanfaatan koleksi perpustakaan dalam memenuhi kebutuhan informasi masyarakat di Perpustakaan Puskesmas Kusuma Bangsa Pekalongan (Skripsi). Universitas Diponegoro, Semarang. Retrieved from http:/ / eprints.undip.ac.id/40988/

Badan Pengembangan dan Pembinaan Bahasa. (2018). Kamus besar bahasa Indonesia (KBBI). Retrieved November 20, 2018, from https://kbbi.web.id/narapidana Jaeni. (2017). Nilai-nilai pengetahuan lokal pembentuk karakter bangsa dalam sandiwara Cirebon, Jawa Barat. MUDRA: Jurnal Seni Budaya, 32(1), 18. Retrieved from https://jurnal.isidps.ac.id/index.php/mudra/article/ view $/ 65$

Junandi, S. (2018). Keterpakaian dan relevansi Jurnal Agritech sebagai rujukan artikel jurnal ilmiah internasional terindeks Scopus. Jurnal Kajian Informasi \& Perpustakaan, 6(1), 95-108.

https:/ / doi.org/10.24198/jkip.v6i1.1 5066

Lalu, C. L., Kimbal, M., \& Pangemanan, S. (2017). Pembangunan berbasis kearifan lokal di Desa Temboan Kecamatan Langowan Selatan Kabupaten Minahasa. Jurnal Eksekutif, 1(1), 1-11. Retrieved from https:/ / ejournal.unsrat.ac.id/index.p hp/jurnaleksekutif/article/view/167 $89 / 16291$

Pattah, S. H. (2014). Literasi Informasi : Peningkatan Kompetensi Informasi Dalam Proses Pembelajaran. Jurnal Ilmu Perpustakaan $\mathcal{E} \quad$ Kearsipan Khizanah Al-Hikmah, 2(2), 119.

Persia, A. N., \& Rohmiyati, Y. (2013). Peran Perpustakaan Anak di Rumah Sakit Kanker "Dharmais" Jakarta. Jurnal Ilmu Perpustakaan, 2(3), 1-8. Retrieved from https://media.neliti.com/media/pu blications/102823-ID-peranperpustakaan-anak-di-rumah-sakitk.pdf

Rahmawan, D. (2016). Buku LP Lowokwaru diharap bisa jadi inspirasi. Retrieved November 20, 2018, from https:/ / malangvoice.com/buku-lp- 
lowokwaru-diharap-bisa-jadi-

inspirasi/

Ranganathan, C., \& Durga, D. (2016). Information literacy among the students in the electronic environment: A case study of Bharathidasan University, Trichy. Journal of Advances in Library and Information Science, 5(3), 262-267. Retrieved from http://jalis.in/pdf/53/Ranga.pdf

Saputro, B. I., \& Amir, C. (2018). Kompetensi pustakawan perpustakaan khusus: Studi kasus di Perpustakaan Kementrian Pendidikan dan Kebudayaan. Baca: Jurnal Dokumentasi Dan Informasi, 39(2), 207-218. https://doi.org/10.14203/j.baca.v39i 2.428

Selvina, H. (2017). Peran lembaga pemasyarakatan dalam penanggulangan kekerasan yang dilakukan oleh narapidana: Studi pada Lembaga Pemasyarakatan II B Kotaagung. Jurnal POENALE, 5(2), 110.

Retrieved

from http://jurnal.fh.unila.ac.id/index.ph $\mathrm{p} /$ pidana/article/view/842/726

Silvana, T., Fitriawati, \& Saepudin, E. (2017). Studi tentang kemampuan literasi informasi di kalangan siswa menengah pertama. Jurnal Edulib, 7(2), 17-28. https://doi.org/10.17509/edulib.v7i 2.9488

Sriyanto, Kurniawan, E., \& Aji, H. S. (2019). Local wisdom of Kandri Village as a form of environmental conservation. In Proceedings of the International Conference on Rural Studies in Asia (ICoRSIA 2018) (pp. 182-184). Semarang: Atlantis Press. https://doi.org/10.2991/icorsia18.2019.44

Subakti, A. (2018). Lapas Narkotika Klas IIA Kaliurang jadi contoh lapas sadar literasi Yogyakarta. Retrieved November 20, 2018, from https://www.perpusnas.go.id/news

detail.php?lang=id\&id=180503054643 TNAPxrGYCJ

Surachman, A. (2013). Manajemen perpustakaan khusus. In BIMTEK Direktorat Jenderal Budidaya Perikanan, Kementerian Perikanan dan Kelautan RI. Jakarta: Direktorat Jenderal Budidaya Perikanan, Kementerian Perikanan dan Kelautan RI. Retrieved from https://repository.ugm.ac.id/136168 /1/Manajemen Perpustakaan Khusus di Era Global.pdf

Tambunan, K. (2013). Kajian perpustakaan khusus dan sumber informasi di Indonesia. Jurnal Dokumentasi Dan Informasi, 34(1), 29-46. https://doi.org/10.14203/j.baca.v34i 1.172 
